http://dx.doi.org/10.7494/human.2012.11.2.93

\title{
Justyna Struzik*
}

\section{PUBLICZNA SOCJOLOGIA QUEER}

Filozofowie rozmaicie tylko interpretowali świat; idzie jednak o to, aby go zmienić 1 .

(Marks 1975: 8)

Powinniśmy stać się katalizatorami rozwiniętej racjonalnej argumentacji przeciwko zwolennikom ograniczania czy zamykania i ortodoksji oraz przeciwko tym wszystkim, którzy próbują udaremnić otwartą publiczną debatę moralną, odwołując się do argumentów tendencyjnych czy fundacjonalnych.

(Seidman 2006: 54)

\begin{abstract}
W niniejszym artykule przedstawiam założenia socjologii publicznej na podstawie prac Micheala Burawoya i społecznej teorii queer według Stevena Seidmana. Zastanawiam się nad możliwością połączenia tych dwóch stanowisk, które, pomimo pewnych różnic, zdają sie być komplementarne. Teoria queer w dużym stopniu wciąż pozostaje nieobecna na gruncie socjologii. Wzbogacenie jej o publiczny aspekt może przyczynić się do rozwoju tej teorii w ramach socjologii.
\end{abstract}

Słowa kluczowe: socjologia publiczna, społeczna teoria queer, Michael Burawoy, Steven Seidman

Próba połączenia perspektywy queer z założeniami socjologii publicznej nie wydaje się być czymś zaskakującym. Obie te perspektywy teoretyczne i badawcze mają bowiem ze sobą na pierwszy rzut oka wiele wspólnego; teoria (czy raczej teorie) queer uwrażliwia na obecność wszystkiego, co nienormatywne, wyrzucone na margines lub poza dominujący dyskurs seksualności, zaś socjologia publiczna podkreśla konieczność działania na rzecz tych „publiczności”, które do tej pory pozostawały nieobecne w dyskursie socjologicznym. Ta pierwsza, choć nierzadko oskarżana o abstrakcyjny tekstualizm, odwołuje się często do swojego zakorzenienia w walce politycznej przeciwko konserwatywnej i antyobywatelskiej postawie władzy w czasach pandemii wirusa HIV w latach 80. w Stanach Zjednoczonych (Seidman 1996: 10); ta druga

* Uniwersytet Jagielloński; justyna.struzik@gmail.com

1 Powyższy cytat, stanowiący XI tezę Marksa o Feuerbachu, jest mottem przewodnim (wraz z tezą X) kluczowego tekstu Micheala Burawoya The Critical Turn to Public Sociology. W tezie tej Marks sprzeciwia się filozofii młodych heglistów, którzy poddając świat społeczny kolejnej filozoficznej interpretacji, tak naprawdę, zdaniem Marksa, nie dostrzegają mechanizmów działania społeczeństwa i w ten sposób nie przyczyniają się do zmiany społecznej. Podobnie, zdaniem Burawoya, socjologia radykalna lat 70. przyczyniła się co prawda do zmian w socjologii, ale swym programem nie objęła już społeczeństwa (Burawoy 2005: 313-314). 
zaś, zgodnie z założeniami Michaela Burawoya (2009a), przywołuje spuściznę wielu socjologów i badaczy społecznych, takich jakich Pierre Bourdieu, Charles Wright Mills, Michael Warner, którzy często wzbogacali etos akademika także o aspekt działacza walczącego przeciw nierównościom i opowiadającego się za afirmacją wybranych grup społecznych. Socjologia publiczna ma się przyczynić ponadto do rozwoju (czy uwidocznienia) nurtu refleksyjnego w socjologii, który zdominowany został na Zachodzie przez nurt instrumentalny (Burawoy 2009a: 546). Oba projekty (choć z pewnością nie tylko one) nawiązują do dorobku studiów feministycznych czy postkolonialnych, które podały w watpliwość rolę i pozycję badacza społecznego, dystansującego się od swojego obiektu badań, czyli społeczeństwa.

$\mathrm{Z}$ ideą połączenia tych dwóch perspektyw po raz pierwszy spotkałam się stosunkowo niedawno - podczas 10. konferencji organizowanej przez European Sociological Association w Genewie w 2011 roku, w ramach grupy tematycznej „Sexuality”. Miałam tam okazję wysłuchać wystapienia Any Cristiny Santos, socjolożki z Centre for Social Studies działającym przy Uniwersytecie w Coimbrze, która na podstawie własnego doświadczenia jako badaczki społecznej w Portugalii zwróciła uwagę na podobieństwo omawianych stanowisk, a nawet ich nierozłączność ${ }^{2}$. Prezentacja ta stała się inspiracją do powstania niniejszego tekstu. W pierwszej części artykułu omówię założenia zarówno socjologii publicznej, jak i społecznej teorii queer, wprowadzanej do socjologii przez Stevena Seidmana. Następnie zastanowię się nad możliwością połączenia tych dwóch perspektyw, także w odniesieniu do polskich realiów.

Wyprzedzając nieco fakty, warto wspomnieć już teraz, że obie te koncepcje rozwijały się głównie w odniesieniu do społeczeństwa amerykańskiego i tamtejszej myśli społecznej. Nawet jeśli przyjmiemy, że założenia tych teorii można przełożyć na inne konteksty społeczne, to jednak rodzi to dodatkowe pytania o zasady owej ,przekładalności” (oczywiście nie tylko w sensie lingwistycznym) i użyteczności amerykańskich idei w lokalnych warunkach³ W wypadku socjologii publicznej pod znakiem zapytania postawić możemy choćby znaczenie polskich słów ,publiczność”, ,publiczny”, które w tym pierwszym wypadku kojarzy się raczej $\mathrm{z}$ bierną widownią, zaś $\mathrm{w}$ drugim ze sferą publiczną ${ }^{4}$. Angielskie słowa public czy publicity odnoszą się raczej do wymiaru zdecydowanie obywatelskiego, co wyraźnie widać choćby u samego Burowaya (2005: 324-325). Z kolei w odniesieniu do aplikacji teorii queer do kontekstu polskiego ciekawym głosem wydaje się być niedawno wydana książka pod redakcją Roberta Kulpy i Joanny Mizielińskiej De-Centring Western Sexualities. Central and Eastern European Perspectives, w której redaktorzy określają status Europy Środkowo-Wschodniej mianem „współczesnej peryferii”, wskazując tym samym z jednej strony na jej geograficzną przynależność do kontynentu, $\mathrm{z}$ drugiej zaś na proces ciągłego dorównywania krajom zachodnim (Kulpa, Mizielińska 2011: 18). Zgodnie z zachodniocentrycznym punktem widzenia, kraje, które po upadku komunizmu stały się częścią demokratycznej Europy, wzorując się na niej, będą dążyć do pokonania kulturowej, ekonomicznej i politycznej przepaści, która je od

Zob. Abstract Book-ESA 2011, dostęp online: http://imatis.unige.ch/conference/abstractbooks/ [29.12.2011].

3 Ciekawa w tym kontekście wydaje się dyskusja prowadzona w strukturach International Sociological Association między Piotrem Sztompką a Michealem Burowayem, odnosząca się do lokalności/narodowości i globalności socjologii.

4 Podobnie jest w wypadku terminu queer, który zdaje się nie mieć odpowiednika w języku polskim, stąd też najcześciej jest dziś stosowany w swej angielskiej wersji. To z kolei może powodować liczne nieporozumienia dotyczące jego znaczenia i sprawiać, że jest on zrozumiały tylko dla nielicznych (Mizielińska 2006: 132-139). 
niej dzieli. Autorzy wprowadzają pojęcie „zapętlonego czasu” (knotted time), dzięki któremu pokazują, w jaki sposób i w jakim czasie w tej części Europy pojawiały się i wciąż pojawiają różnego rodzaju koncepcje odnoszące się do kategorii gender lub seksualności, które na Zachodzie konstruowane były w porządku linearnym, jedna po drugiej (Kulpa, Mizielińska 2011: 16). „Zapętlony czas” pojawiających propozycji teoretycznych w tej części Europy rodzi problemy przy interpretacji wielu zjawisk społecznych:

(...) Silnie asymilacyjny model aktywizmu obecny dziś w Europie Środkowo-Wschodniej (...) może być odczytany jako „krok wstecz” do czasów ,zachodnich ruchów homofilnych” w latach 50. i 60. Tymczasem ten „krok wstecz” może oznaczać tak naprawdę ,krok do przodu” dla gejów i lesbijek w EŚW, choćby dlatego, że od roku 1989 mogą się swobodnie zrzeszać (Kulpa, Mizielińska 2011: 16).

Problematyczny staje się więc sposób, w jaki należy interpretować społeczne zjawiska odnoszące się do seksualności (np. działalność ruchu LGBT ${ }^{5}$ w Polsce) oraz to, czy narzędzia, którymi dysponujemy (np. teoria queer), są właściwe dla naszego kontekstu kulturowego. Innymi słowy, przywołuję tę książkę nie po to, by wskazać ,prowincjonalność” (co nie jest w żadnym wypadku moim celem) społeczeństwa polskiego wobec Zachodu, lecz po to, by pokazać, że teoria queer niekoniecznie musi być narzędziem najbardziej produktywnym w analizie sytuacji społeczności LGBT. Warto tu także dodać, że mimo procesów demokratyzacyjnych, liberalizacji światopoglądowej Polaków i Polek w ciągu ostatnich dwóch dekad, sytuacja ta nie uległa widocznej zmianie. Prawo polskie wciąż pomija potrzeby tejże społeczności (wyjątek stanowi kodeks pracy), zaś dyskurs publiczny przepełniony jest homofobiczną mową nienawiści. W miejscu tym, ze względu na poruszaną problematykę, a także założenia przedstawianych koncepcji, ważne wydaje się też, bym sama odniosła się do mojego umiejscowienia w relacjach zarówno z socjologią, jak i jej publicznościami. Jestem badaczką społeczną, która zajmuje się społecznym konstruowaniem seksualności w polskim ruchu LGBT, za którego uczestniczkę także się uważam. To podwójne umiejscowienie, z jednej strony w kręgu nauki, z drugiej zaś w kręgu ruchu społecznego, choć niesie ze sobą liczne możliwe zagrożenia, daje w mojej opinii okazję do głębszej analizy rzeczywistości społecznej, a także wpisuje się w założenia socjologii publicznej.

\section{SOCJOLOGIA PUBLICZNA}

Naukowiec nie powinien być tylko naukowcem, ale również obywatelem. To jest istota, raison d'etre socjologii.

(Burawoy 2010)

Zdaniem Michaela Burawoya socjologia publiczna nie jest zjawiskiem nowym, a w historii socjologii znaleźć możemy wiele egzemplifikacji postaw badawczych, które wpisują się w założenia omawianego projektu. Socjologia publiczna jest w pewnym sensie odpowiedzią na kryzys socjologii jako dyscypliny naukowej, która choć przez ostatnie sześćdziesiąt lat rozwijała się niezwykle prężnie (zwłaszcza jeśli chodzi o jej aspekt teoretyczny), to jednak,

\footnotetext{
5 Ruch na rzecz lesbijek, gejów, osób biseksualnych i transpłciowych.
} 
zdaniem Burawoya (2005: 313-314), odcięła się od świata, do którego reprezentacji rościła sobie prawo. Autor Manufacturing Consent wskazuje na kluczowy dla przemian w socjologii okres lat 70., kiedy to śledziliśmy potężny rozkwit nowych ruchów społecznych, protestów, ulicznych walk i alternatywnych narracji tożsamościowych (Burawoy 2005: 314-319). Celem ówczesnej socjologii radykalnej czy krytycznej stało się więc uchwycenie tych zmian, wypełnienie luki teoretycznej koncepcjami, które pozwoliłby zrozumieć owe rewolucje. Należało zmienić socjologię. Radykalizowano więc teorię w obrębie akademii, tworzono kolejne utopie, nie dotykając jednak często tkanki społecznej. Dziś natomiast, na początku XXI wieku, sytuacja wydaje się być, zdaniem Burawoya, odwrotna. Społeczeństwa, zarówno te globalne, jak i lokalne, poddawane są coraz większej kontroli ze strony rynków i państwa, która wzmocniła się dodatkowo po upadku komunizmu w Europie Środkowo-Wschodniej oraz wydarzeniach 11 września 2001 roku (Burawoy 2005: 318). Jednak na całym świecie są widoczne działania społeczne, które nie uległy owej tyranii; są nimi wciąż obecne ruchy społeczne i szeroko rozumiane aktywności obywatelskie. To właśnie w tym kierunku powinna się zwrócić współczesna socjologia. „Krytyczny zwrot” naszej dyscypliny ku socjologii publicznej jest, zdaniem Burawoya, zarówno konieczny, jak i możliwy (Burawoy 2005: 324). Konieczność ta wynika z tzw. ruchu nożyc, który Burawoy opisuje w następujący sposób:

Zapotrzebowanie na socjologię publiczną jest tym większe, a jej realizacja tym trudniejsza, im bardziej socjologia przesuwa się na pozycje lewicowe, a badany przez nią świat staje się coraz bardziej prawicowy (Burawoy 2009a: 527).

Dominacja mechanizmów rynkowych w każdym aspekcie życia społecznego, powodująca wzrost nierówności społecznych i osłabienie społeczeństw obywatelskich, zmusza niejako socjologię do współpracy z organizacjami, grupami, ruchami społecznymi na rzecz zmiany, do wzięcia udziału w debatach dotyczących publicznych, bo dotykających wszystkich obywateli i obywatelki, problemów. Ponadto Burawoy, analizując wyzwania stojące przed socjologią w okresie trzeciej fali marketyzacji, zwraca uwagę na konieczność myślenia o zmianie społecznej czy działaniach na rzecz publiczności w kategoriach globalnych, co nie powinno jednak oznaczać hegemonii socjologii amerykańskiej (Burawoy 2007: 365).

Z kolei możliwość owego „krytycznego zwrotu” ku publicznej socjologii wynika ze „spontanicznej relacji socjologii ze społeczeństwem obywatelskim” (Burawoy 2005: 324). Relacja ta nie powinna być jednak pozbawiona krytycznego spojrzenia na funkcjonowanie społeczeństwa obywatelskiego (stąd termin „krytyczny zwrot”). Socjologia powinna więc śledzić relacje władzy ukryte w tkance społecznej i dążyć do ich zniesienia. Ta wrażliwość na nierówności, wykluczenie czy hierarchizację jest niezwykle ważna, bowiem, jak podkreśla brytyjski socjolog:

(...) społeczeństwo obywatelskie może być bronią autorytarnych i faszystowskich reżimów tak łatwo jak może bronić ludzkość przed dyktaturą (Burawoy 2005: 324).

Rola, którą przypisuje więc socjologii publicznej, ma polegać na:

(...) uczynieniu społeczeństwa obywatelskiego nie tylko silnym i autonomicznym, ale także demokratycznie zarządzanym, odpowiadającym różnorodnym interesom, a także przenikającym państwo (Burawoy 2005: 324-325). 
Podobnie państwo winno otworzyć się na sprawy i głosy swoich obywateli i obywatelek, na ich partycypację w podejmowaniu kluczowych dla nich decyzji. Socjologia ma się kierować „prawdziwymi, realnymi utopiami”, które osadzone i ugruntowane są w rzeczywistości społecznej.

Stanowisko Burawoya wydaje się być zbieżne z perspektywą Zygmunta Baumana (przynajmniej z pewnego okresu jego twórczości naukowej), także podkreślającego konieczność kierowania się utopiami, które są bliżej życia społecznego. Za Rusellem Jacobem Bauman przywołuje podział modernistycznych utopii na utopię blueprint - utopię planu, którego celem było zagospodarowanie i podporządkowanie sobie społeczeństwa - oraz utopię obrazoburczą (iconoclastic), która miała koncentrować się przede wszystkim na krytycznym odczytywaniu rzeczywistości społecznej, nie zaś na tworzeniu konkretnych planów ulepszania ludzkości (Bauman 2010: 51). Ta druga wizja wydaje się być Baumanowi bliższa. Pisze on bowiem:

(...) proponuję rozpakować pojęcie „iconoclastic utopia” poprzez skupienie się (...) na krytycznej rewizji drogi i znaczenia współczesnego życia jako głównych czynnikach odkrywania wyciszonej, skrywanej czy dotąd nieznanej możliwości „innego gdzie-indziej” lub innej „rzeczywistości społecznej” (Bauman 2010: 51).

Wracając do rozważań Burawoya, warto zastanowić się także nad jego rozumieniem „publiczności”. Esencję socjologii publicznej stanowi „rozmowa z publicznością”, ludźmi, grupami społecznymi, którzy biorą udział w dialogu z badaczami społecznymi (Burawoy 2009a: 530). Publiczność jako taka nie jest elementem stałym, co należy poddać analizie, jest raczej w procesie ciągłej zmiany, zaś my jako socjologowie powinniśmy temu procesowi bacznie się przyglądać, być może także brać w nim udział. Socjolog publiczny nierzadko sam kreuje, stwarza publiczność, wiele grup bowiem pozostaje niewidocznych w mainstreamowych dyskursach, zwłaszcza w okresie ich kolonizacji przez rynek, dopóki badacze społeczni nie zaczną działać na rzecz, czy raczej z owymi grupami, czyniąc ich głos słyszalnym. Sam Burawoy woli mówić o wielości socjologii publicznych, wskazując tym samym na jej liczne odmiany. Jak więc mogłyby wyglądać owe rozmowy z publicznością? Tradycyjna socjologia publiczna ogranicza się do brania udziału w publicznych dyskusjach w ramach dostępnych mediów, np. dzienników czy programów telewizyjnych, w których socjolog może prezentować głos odnoszący się do danych problemów społecznych (Burawoy 2009a: 530). Tutaj jednak publiczność sprawia wrażenie dość pasywnej, co prawda bierze udział w tejże dyskusji, rzadko jednak kreuje ruch społeczny na rzecz zmiany, choć jest to możliwe. Ten model socjologii publicznej zdaje się być obecny także w Polsce, trudno bowiem nie dostrzec wielości socjologicznych głosów w debatach politycznych, choć bardziej problematyczna wydaje się ich relacja wobec konkretnych publiczności, a także „socjologiczność” przekazywanej wiedzy.

Wydaje się, że bardziej kluczowa dla rozwoju samej socjologii jako dyscypliny jest komplementarna wobec tradycyjnej organiczna socjologia publiczna, „(...) w ramach której socjologowie pracują w bliskiej relacji z widoczną, gęstą, aktywną, lokalną i często stojącą w opozycji wobec głównego nurtu społeczeństwa, publicznością” (Burawoy 2009a: 530). W takim wypadku socjolog publiczny jest więc tym, który współpracuje z różnego rodzaju grupami, związkami, ruchami społecznymi i choć często działania te pozostają niewidoczne, 
bo traktowane są jako prywatne, tuż obok publicznej tożsamości socjologa akademika, to jednak ich rola jest nie do przecenienia.

Socjologia publiczna nie istnieje oczywiście w oderwaniu od innych rodzajów socjologii, tak jak socjologia praktyczna, profesjonalna (akademicka) czy też krytyczna. Kluczowa dla rozwoju wszystkich rodzajów socjologii wciąż pozostaje socjologia akademicka, która dostarcza idee i koncepcje dla publicznej i praktycznej socjologii, a także stanowi punkt wyjścia dla socjologii krytycznej. Wszystkie cztery socjologie wzajemnie się przenikają (lub powinny przenikać) i wpływają na swój rozwój. W swym przemówieniu prezydenckim w American Sociological Association z 2004 roku Burawoy dokonuje dokładnej analizy tych zależności, pokazując m.in., że „socjologia krytyczna jest sumieniem socjologii akademickiej w takim samym stopniu, w jakim socjologia publiczna stanowi sumienie socjologii praktycznych" (Burawoy 2009a: 535). Socjologie publiczne i praktyczne, w odróżnieniu od akademickich i krytycznych, swoje przesłanie kierują w dużym stopniu do publiczności pozaakademickich, choć różni je od siebie to, że te publiczne, wykorzystując wiedzę refleksyjną, przyglądają się celom zarówno projektów naukowych i badawczych, jak i debatom toczonym z publicznościami. I choć założenia Burawoya (2009b: 455-457) poddane zostały ostrej krytyce, głównie ze strony socjologów akademickich, to wydają się być one wciąż zbyt mało przedyskutowane, także na gruncie polskiej socjologii ${ }^{6}$. Brytyjski socjolog częstokroć zwraca uwagę także na to, że sama nauka czy świat akademicki budowane są nierzadko na podstawie hierarchii i władzy. W wywiadzie udzielonym Michałowi Łuczewskiemu podczas swojego pobytu w Warszawie w 2010 roku Burawoy mówił:

Choć uważam, że socjologia nie może rozwijać się bez socjologii profesjonalnej, to widzę również, że sama socjologia jest polem dominacji. Jeśli podważasz dominację, pojawia się konflikt. Socjologowie mają swoje interesy, ich reputacja oparta jest na wiedzy, którą produkują walidowanej przez recenzje. Obawiają się, że kiedy zaczną być odpowiedzialni również przed współobywatelami, naukowość ich pracy zostanie podana w wątpliwość. Interes socjologii profesjonalnej jest sprzeczny z interesem socjologii publicznej. To wojna. To konflikt (Burawoy 2010).

\section{SPOŁECZNA TEORIA QUEER}

Teoria queer w dużym stopniu wciąż pozostaje nierozpoznana przez socjologię. Tworzona i rozwijana głównie w literaturoznawstwie i filozofii nie zawsze znajduje swoje miejsce w socjologicznych rozważaniach (Seidman 1996: 12-13). Wielu badaczy i teoretyków krytykuje podejście queer za przesadny tekstualizm, oderwanie od rzeczywistości społecznej i tworzenie abstrakcyjnych, często niemających wiele wspólnego z doświadczeniem realnego, materialnego życia społecznego, narracji na temat seksu i seksualności (Beasley 2005: 170-171). Ponadto często wskazuje się, że socjologia jako dyscyplina naukowa nie jest pozbawiona przemyśleń,

${ }^{6}$ Z pewnością na uwagę zasługuje działalność Koła Naukowego Socjologii Publicznej Instytutu Socjologii Uniwersytetu Warszawskiego, które pod opieką dr. Macieja Gduli propaguje idee socjologii publicznej na gruncie polskiej nauki. 
teorii czy badań dotyczących seksualności, czego teoretycy queer zdają się nie zauważać7 Wręcz przeciwnie - podkreślić należy jej długą i bogatą tradycję w badaniach tematycznych w nurcie interakcjonizmu symbolicznego (zob. Gagnon, Simon 2005), koncepcję roli homoseksualnej Mary McIntosh czy choćby wspomnieć np. prace Jeffreya Weeksa, pisane w duchu konstrukcjonizmu społecznego. Kolejnym punktem krytyki wobec teorii queer jest niezauważanie przez nią kwestii klasowych, a także innych kategorii społecznych, takich jak etniczność. Zdaniem Donalda Mortona (1996: 1-33) teoretycy i teoretyczki queer przesadnie skupiają się na analizie gender czy seksualności w wymiarze pożądania, traktując je jako performans, tekst czy dyskurs, nie zwracając uwagi m.in. na procesy rynkowe, w które te kategorie są uwikłane. Spotkania teorii queer z socjologią nie są więc ani łatwe, ani częste. Niemniej jednak teoria ta, silnie zakorzeniona w myśli postmodernistycznej, wciąż wydaje sie być ciekawą propozycją teoretyczną i dobrym narzędziem do analizy relacji władzy, mechanizmów hierarchizacji i normalizacji seksu, seksualności i gender.

Jednym z głównych teoretyków, który przyczynił się do wprowadzenia perspektywy queer na grunt socjologii, jest bez wattpienia Steven Seidman. Jego koncepcja społecznej teorii queer wpisuje się $\mathrm{w}$ szerszą dyskusję na temat roli teorii $\mathrm{w}$ socjologii $\mathrm{w}$ okresie ponowoczesności. Seidman jest zwolennikiem teorii społecznej zasadniczo odmiennej, jego zdaniem, od teorii socjologicznej (Seidman 2006: 44-55). Ta pierwsza, silnie zakorzeniona w konfliktach społecznych i uznawana nierzadko za ideologiczna, stawia sobie za cel nie tylko wyjaśnienie przyczyn zjawisk zachodzących w danym społeczeństwie, ale także zakłada możliwą interwencję w rzeczywistość społeczną. Ta druga z kolei dąży do wyabstrahowania się z kontekstu społecznego i wykrycia pewnych uniwersalnych logik rządzących społeczeństwem (ibidem). Seidman nie ukrywa, że bliższa jest mu wizja teorii społecznej, domaga się porzucenia poszukiwań „wszechobejmującej teorii ogólnej” na rzecz koncentracji na lokalnych kontekstach. Nie oznacza to jednak całkowitego odejścia od tego, co nazywa wielkimi narracjami społecznymi. Mogą one wciąż odgrywać, i ogrywają ważną rolę, pod warunkiem ich silnego zakorzenienia w tym, co lokalne, kontekstowe oraz możliwości ujawnienia innych, alternatywnych narracji. W myśli Seidmana możemy też dostrzec silny zwrot ku zaproponowanym przez Burawoya ,publicznościom”, pisze on bowiem:

Powinniśmy stać się rodzajem katalizatora dla moralnych i społecznych publicznych debat. (...) Nasza rola polegałaby zarówno na dostarczaniu nastawionych społecznie analiz, użytecznych dla poszczególnych stron, jak i na propagowaniu swobodnej, niepodlegającej żadnemu przymusowi publicznej debaty moralnej w obliczu zwolenników różnych rozwiązań, którzy wciąż na nowo starają się ograniczyć taki rozbudowany dyskurs (Seidman 2006: 54).

Na podstawie tych założeń Seidman wprowadza społeczną teorię queer odnoszącą się do społeczeństwa amerykańskiego i w nim umiejscowioną. Autor The Social Construction of Sexuality, pisząc o konstruktach innej niż heteroseksualna seksualności, zwraca uwagę na

\footnotetext{
Warto zwrócić uwagę na niedawną debatę nad książką Jacka Kochanowskiego Spektakl i wiedza. Perspektywa społecznej teorii queer, która odbyła się na łamach „Societas/Communitas”. Książce zarzucono m.in. słabe ugruntowanie w klasycznych teoriach socjologicznych, odnoszących się do problematyki „inności”. Por. „Societas/Comunitas" 1(11) 2011, s. 219-250.
} 
ograniczenia wytwarzania i reprodukowania kategorii geja czy lesbijki przez ruchy społeczne, które łączą się zazwyczaj z pojęciem normalizacji (Seidman 2002:133). Innymi słowy, dla Seidmana np. znormatywizowane pojęcie ,gej” jest zawsze powiązane z wcześniej istniejącymi lub właśnie rodzącymi się normami społecznymi, takimi jak monogamia, nieprzekraczanie granic tożsamości genderowych, płciowość, wartości rodzinne i ekonomiczny dobrobyt.

\section{PUBLICZNA SOCJOLOGIA QUEER?}

Starając się odpowiedzieć na pytanie o możliwość połączenia perspektyw i założeń socjologii publicznej i teorii queer (choć w obu przypadkach mówimy raczej o ogólnych zarysach tych koncepcji ze względu na ich wewnętrzną złożoność i różnorodność, a często także fragmentaryczność), na zakończenie chciałabym przedstawić argumenty zarówno „za”, jak i „przeciw” zaproponowanemu projektowi, także w odniesieniu do polskiej socjologii. Warto także zaznaczyć, że w moim zamyśle to raczej socjologia publiczna miałaby stanowić wsparcie dla teorii queer, zwłaszcza przy próbie jej głębszego włączenia do socjologii, a nie odwrotnie.

Przyjrzyjmy się więc specyfice działań podejmowanych przez socjologów poruszających się w obszarze socjologii queer. Po pierwsze doświadczenie ruchów społecznych, działających na rzecz gejów, lesbijek, osób biseksualnych czy transpłciowych, zarówno na Zachodzie, jak i w Polsce pokazuje, że bardzo często aktywności te wspierane były przez socjologów i socjolożki nie tylko symbolicznie, ale także poprzez uczestnictwo i zaangażowanie. Wielu z nich bez wahania można by określić mianem socjologów publicznych. Ich udział był widoczny nie tylko podczas marszów, parad czy publicznych spotkań, ale także w mediach. W kontekście polskim warto przypomnieć tu choćby dyskusję zapoczątkowaną w roku 2002 na łamach „Gazety Wyborczej” tekstem polskiego socjologa Jacka Kochanowskiego Geje nie będa udawać matżeństw, poruszającym problem wykluczenia związków jednopłciowych z prawa do samostanowienia o życiu rodzinnym. Tekst ten wywołał głośną, publiczną debatę, w której udział wzięli także inni socjologowie, m.in. Ireneusz Krzemiński, przedstawiciele innych dyscyplin i publicyści. Podobną postawę reprezentuje wiele polskich socjologów i socjolożek. Z naszego krakowskiego podwórka należy wymienić choćby Beatę Kowalską, która choć określa się jako socjolożka krytyczna, od lat bierze udział w wielu wydarzeniach, zarówno feministycznych, jak i na rzecz lokalnej społeczności LGBT.

Taki obraz socjologii polskiej musi być siłą rzeczy fragmentaryczny, trudno jest mi bowiem choćby zarysować całościową wizję tejże dziedziny w murach polskiej akademii. Z pewnością nie należy zapominać o dorobku wielu polskich badaczy i badaczek społecznych, którzy rozwijali myśl krytyczną socjologii (por. Mucha 2010). Sama wizja socjologii publicznej wydaje się być jednak w Polsce nieobecna.

Po drugie to, jakby się mogło wydawać, oczywiste połączenie teorii queer z socjologią publiczną wynikać może ze specyfiki samej publiczności, którą zdają się być w najwęższym rozumieniu geje, lesbijki, osoby biseksualne i transpłciowe, w najszerszym zaś wszystkie osoby o nienormatywnej tożsamości seksualnej czy płciowej. W wielu krajach społeczność LGBT doświadcza wykluczenia społecznego, dyskryminacji, a nawet przemocy fizycznej czy 
seksualnej. Społeczność ta jest nierzadko współkreowana także przez socjologów i socjolożki, którzy pracując na jej rzecz i wraz z nią, publikując artykuły czy książki, biorąc udział w debatach publicznych, czynią temat ten widocznym w publicznym dyskursie. Można tu przywołać choćby konferencję „Homoseksualizm: sprawa prywatna czy publiczna? Perspektywa interdyscyplinarna", zorganizowaną w 2004 roku przez Instytut Socjologii Uniwersytetu Jagiellońskiego jako wydarzenie towarzyszące lokalnemu festiwalowi społeczności LGBT „Kultura dla Tolerancji”. Wbrew oczekiwaniom organizatorek konferencja ta spotkała sie z homofobicznymi reakcjami, także ze strony środowiska naukowego (Slany, Kowalska, Śmietana 2005: 7-16). Nie ulega jednak wątpliwości, że tego typu działania, z jednej strony silnie zakorzenione w aktywnościach obywatelskich i ruchach społecznych, z drugiej zaś przyczyniające się do tworzenia i przekształcania danej publiczności, można zaliczyć do działań socjologii publicznych.

Po trzecie teoria queer, także w kontekście polskim, zdaje się dostrzegać konieczność działania na rzecz społeczeństwa obywatelskiego, nie zapominając tym samym o krytycznym spojrzeniu na jego funkcjonowanie w zakresie relacji władzy i dominacji. Socjologowie queer często zajmują stanowisko krytyczne wobec samej społeczności LGBT, pokazując dodatkowo, że praktyki tej grupy mogą się także wykluczać. I tak np. wspomniany Steven Seidman dostrzega duże niebezpieczeństwo w procesie normalizacji społecznej kategorii geja, która choć stała się w Stanach Zjednoczonych akceptowana, to jednak tolerowana jest tylko w konkretnej, łatwo przyswajalnej przez społeczeństwo formie. Pokazuje więc tym samym, że pewne kategorie, które służą do budowy społeczeństwa obywatelskiego, mogą stać się kategoriami wykluczającymi. Na podobne zjawisko zwraca uwagę także Judith Butler, jedna z twórczyń teorii queer, pisząc:
A jeśli tożsamość jest koniecznym błędem, konieczne jest uznanie terminu queer jako określenia przynależności, nieopisującego jednak w pełni tych, których ma reprezentować. W rezultacie trzeba będzie potwierdzić przypadkowość samego terminu: pozwolić, by został obalony przez tych, któ- rych wyklucza, a którzy słusznie oczekują, że będzie ich reprezentował; pozwolić by przyjął nowe, niemożliwe do przewidzenia znaczenie nadane mu przez młodsze pokolenie, którego terminologia polityczna może być związana z zupełnie innymi celami (Butler 2006: 538).

W kontekście europejskim o podobnym zjawisku piszą socjolodzy holenderscy, którzy analizują zjawisko „homonacjonalizmu” i pokazują, w jaki sposób prawa osób LGBT, uznawane za holenderskie wartości narodowe, są częstokroć instrumentalnie używane w dyskursie publicznym przeciw mniejszościom etnicznym i religijnym, mieszkającym w Holandii. Przedmiotowe wykorzystanie wartości takich jak różnorodność, otwartość, akceptacja odmienności i różnicy przyczynia się paradoksalnie do wzrostu nastrojów islamofobicznych (Mepschen, Duyvendank, Tonkens 2010).

Teoria queer, mimo że wywodzi się w pewnym sensie z radykalnych działań społecznych, podejmowanych głównie poza akademią w latach 80 . i na początku lat 90 ., w dobie pandemii HIV, to jednak często krytykowana jest za nadmierne teoretyzowanie. Rozważania nad możliwością transgresji dla wielu dalekie się wydają być od rzeczywistości społecznej i problemów społeczności LGBT. Sam Burawoy umieszcza tę perspektywę raczej w obszarze socjologii krytycznej, która za cel stawia sobie demaskowanie władzy głównie w teorii, nie 
zaś poza nią (Burawoy 2005: 535). Być może jednak właśnie wzbogacenie perspektywy queer w socjologii o jej publiczny aspekt okaże się znaczące zarówno dla rozwoju samej socjologii queer, jak i wielu dzisiejszych i przyszłych publiczności, z którymi przyjdzie socjologom współpracować. Socjologowie i socjolożki zgodnie z postulatami Burawoya mogliby więc stać się nie tylko orędownikami zmiany społecznej, ale także, analizując procesy społeczne, brać udział w społecznych debatach i oddawać głos tym, którzy nie mają możliwości go publicznie zabierać.

\section{BIBLIOGRAFIA}

Bauman, Zygmunt. 2010. Living on Borrowed Time. Conversations with Citlali RovirosaMadraso, Cambridge: Policy Press.

Beasley, Chris. 2005. Gender\&Sexuality. Critical Theories, Critical Thinkers, London: Sage. Burawoy, Michael. 2005. The Critical Turn to Public Sociology, „Critical Sociology” 31, s. $313-326$.

Burawoy, Michael. 2007. Public sociology vs. the Market, „Socio-economic Review” 5, s. 356-367.

Burawoy, Micheal. 2009a. O socjologię publicznq. Przemówienie prezydenckie z roku 2004, w: Aleksander Manterys i Janusz Mucha (red.), Nowe perspektywy teorii socjologicznej, Kraków: Zakład Wydawniczy NOMOS, s. 525-561.

Burawoy, Michael. 2009b. The Public Sociology Wars, w: Vincent Jeffries (ed.), Handbook of Public Sociology, Lanham: Rowman and Littlefield, s. 449-473.

Burawoy, Michael. 2010. Wywiad z Michaelem Burawoyem, rozmawiał Michał Łuczewski, Warszawa, dostęp online: http://burawoy.berkeley.edu/Biography/Interview.Poland.1.2010. pdf [30.12.2011].

Butler, Judith. 2006. Krytycznie queer, w: Anna Burzyńska i Michał Paweł Markowski (red.), Teorie literatury XX wieku. Antologia, Kraków: Znak.

Gagnon, John H. i William Simon. 2005. Sexual Conduct: The Social Sources of Human Sexuality. Second Edition. New Brunswick (USA.) and London(UK): AldineTransaction.

Kulpa, Robert i Mizielińska, Joanna. 2011. 'Contemporary Peripheries': Queer Studies, Circulation of Knowledge and East/West Divide, w: Robert Kulpa i Joanna Mizielińska (eds.), De-Centring Western Sexualities. Central and Eastern European Perspectives, London: Ashgate, s. 11-26.

Marks, Karol. 1975. Faksymile 11 tezy o Feuerbachu. Z notatnika Marksa, w: Karol Marks i Fryderyk Engels, Dzieła, t. 3, Warszawa: Książka i Wiedza, s. 5-8.

Mepschen, Paul, Jan W. Duyvendak i Evelien Tonkens. 2010. Sexual Politics, Orientalism and Multicultural Citizenship in the Netherlands, ,Sociology” 44/5, s. 462-479.

Mizielińska, Joanna. 2006. Płeć, ciało, seksualność. Od feminizmu do teorii queer, Kraków: Universitas.

Morton, Donald (ed.). 1996. The Material Queer Theory, New York: Westview Press.

Mucha, Janusz. 2010. Socjologia jednostek i teoria krytyczna. Konferencja lizbońska o aktualnych debatach w socjologii krytycznej, ,Studia Humanistyczne AGH”, t. 8, s. 9-24. 
Seidman, Steven (red.). 1996. Queer Theory/ Sociology. Introduction, Cambridge: Blackwell Publishers.

Seidman, Steven. 2002. Beyond the Closet, The Transformation of Gay and Lesbian Life, New York, London: Routledge.

Seidman, Steven. 2006. Koniec teorii socjologicznej: ponowoczesna nadzieja, w: Aleksandra Jasińska-Kania i inni, Współczesne teorie socjologiczne, Warszawa: Wydawnictwo Naukowe Scholar, s. 44-55.

Slany, Krystyna, Beata Kowalska i Marcin Śmietana. 2005. Wprowadzenie, w: Krystyna Slany, Beata Kowalska i Marcin Śmietana, Homoseksualizm. Perspektywa interdyscyplinarna, Kraków: Zakład Wydawniczy NOMOS, s. 7-16.

\section{PUBLIC QUEER SOCIOLOGY}

In the following paper I present the main assumptions of public sociology on the basis of Michael Burawoy's publications and social queer theory, according to Steven Seidman. In my paper I consider a possibility of connection of those two perspectives, which, even if are different, seem to be complementary. The queer theory still seems to be widely absent in sociology. Enriching the queer theory of „public" issue may contribute to the development of this theory in a framework of sociology.

Key words: public sociology, social queer theory, Michael Burawoy, Steven Seidman 